\title{
Invention, Innovation, and Imitation in India-Necessity Arising from the COVID-19 Pandemic
}

\author{
Joseph L. Mathew ${ }^{1,2} \quad$ T. Lazar Mathew ${ }^{3}$ \\ ${ }^{1}$ Advanced Pediatrics Centre, Postgraduate Institute of Medical \\ Education and Research, Chandigarh, India \\ ${ }^{2}$ National Biomedical Instruments and Devices Hub, Chandigarh, India \\ ${ }^{3}$ Karunya Institute of Technology and Sciences, Coimbatore, \\ Tamil Nadu, India
}

\section{Abstract}

\section{Keywords}

- biomedical innovation

- COVID-19

- respiratory support

- artificial breathing capability device

- innovation pathway

- innovation ecosystem
The COVID-19 pandemic has stimulated tremendous innovation in India, driven by unprecedented novel needs, sense of urgency, availability of time during the lockdown, funding by Government agencies, and accelerated processing of projects. Therefore, the country has witnessed widespread innovation and imitation of existing technologies in recent weeks, but very few inventions. One novel invention, the Artificial Breathing Capability Device (ABCD) is being speeded up by the current necessity. Other innovations and imitations include (i) healthcare devices/products intended for diagnosis, management, or monitoring of suspected/confirmed COVID-19 patients (in healthcare institutions); (ii) improvisations in personal protective equipment (PPE) for frontline healthcare workers and other personnel (including the public); (iii) adaptation of information technology platforms for telehealth, telemedicine, telemonitoring, and tele-education; and (iv) repurposing of existing resources/technologies for COVID-19. Some fruits of these efforts include (i) respiratory support devices (by mechanization of manual ventilation, ventilator splitters, etc.), (ii) personal protective equipment (PPE) (novel face masks, face shields/splash guards, intubation boxes, aerosol guards, etc.), (iii) novel sanitization products, processes or deployment methods, (iv) diagnostic tests (including rapid antibody tests, polymerase chain reaction [PCR] methods, and loop-mediated isothermal amplification [LAMP]), and (v) various adaptations such as repurposing and retrofitting of existing technologies aligned to the needs of COVID-19. These innovations and imitations have laudable features such as extremely rapid development of products (not merely concepts or prototypes); collaboration among individuals, institutions, and industry; willingness of players to work outside traditional comfort zones; and teamwork among stakeholders. Social media and lay press publicity create a sense of achievement and hope in a nation bogged down by the realities of COVID-19. However, these positive developments are associated with unique problems, especially duplication of effort, disregard of intellectual property (IP) issues, unhealthy competition amongst institutions, and failure to consider the needs for which solutions are proposed. The haste for developing products has bypassed the important steps of peer review, laboratory testing, and clinical validation to ensure the safety and efficacy of end users. These unintended side effects of the innovation race can be overcome by coordinated efforts through an innovation pathway proposed in this article under a broader innovation ecosystem.
License terms

(1) (1) $\ominus \circledast$ 


\section{Introduction}

The COVID-19 pandemic has stretched healthcare resources (in terms of manpower, materials, and money) to an unprecedented extent. Concomitantly, the imagination of healthcare and nonhealthcare personnel have also been stretched to find unique solutions to the unprecedented needs created by the pandemic. Thus, innovation has become a buzzword in healthcare delivery today. The boost to innovation has even been hailed as a positive benefit of COVID-19., ${ }^{1,2}$ The intrinsic innovative mindset and approach of Indian professionals and the public have created interesting and offbeat solutions to some of the challenges posed by the pandemic. This article presents some of the major innovations and imitations undertaken in India, without intending to be an extensive catalogue. However, all these innovations and imitations are reported mostly in the lay press, rather than scientific publications. Hence, technical and scientific details are lacking. In some situations, the "innovation" merely represents an improvement or improvisation of existing technologies. Innovative usage of novel or existing pharmacological products, biologicals, or vaccines are outside the scope of this article. Similarly, information technology (IT) solutions through the creation of novel apps are not considered here. Diagnostic tests, platforms, etc. are also outside the scope of this article, but they are described briefly for the sake of completion.

\section{Definition and Scope of Innovation}

The Merriam-Webster dictionary defines innovation simply as a "new idea, method, or device," or alternatively as "the introduction of something new." Similarly, the well-respected Cambridge dictionary defines the term as "the use of a new idea or method"4. The Wikipedia description stresses that innovation is an "original and more effective" product of a novel idea or creative thought. ${ }^{5}$ Thus, all three definitions capture the concept of novelty, although the latter emphasize the additional concept of implementing the novel idea to produce something. The Business Dictionary throws additional light on the term as the "deliberate application of information, imagination and initiative in deriving greater or different values from resources." It emphasizes innovation as the process by which novel ideas are converted into useful products. ${ }^{6}$ In India, the colloquial Hindi word "jugaad" partially captures the concept of innovation as a creative solution from an unconventional use of existing resources. The emphasis is to "make things work, or to create new things with minimal resources."7

It is important to understand the distinction between innovation and invention. The latter clearly describes a novel product or solution, whereas innovation is more likely to be a novel implementation of an existing or new invention. Viewed in this context, innovation need not always stem from an invention.

However, the bottom-line is that invention, innovation and imitation must be driven to satisfy a specific need that is not fulfilled by the existing products, techniques, or processes. In that sense, invention, innovation, and imitation are offspring of the same mother, namely, necessity created by the COVID-19 pandemic.

\section{Indian Inventions, Innovations, and Imitations in the Context of COVID-19}

Since Indians are innovative by nature, a slew of products and processes have been conceived in recent weeks to tackle the challenges posed by COVID-19. Many of these are directly related to healthcare delivery in patients with suspected or confirmed COVID-19, aiding treatment, prophylaxis or diagnosis. Others are indirectly associated with healthcare but are nevertheless important. Some innovations and imitations are more applicable in the domain of public health. Finally, IT platforms provide unique opportunities for telehealth and educational activities. - Table 1 presents a nonexhaustive list of some of the major innovations and imitations impacting healthcare delivery. Some of the more useful products are described subsequently.

\section{COVID-19 Inspired Innovations in India: Boon or Bane?}

The lockdown period provided the most valuable resource to organizations, institutions, individual professionals, and even the lay public-time (in ample quantity). The availability of time and flexibility of working outside the routine systems and schedules created an immense opportunity for innovation. These innovations occurred despite limited access to raw materials, consumables, and traditional supply chains; that too in an environment wherein face-to-face collaboration among colleagues was nearly impossible.

Professionals across disciplines worked together to devise solutions for practical problems. It has also fostered tremendous industry support for initiatives outside the usual mandate of these organizations. This has resulted in mobilization of industry equipment, raw materials, workforce, and even finances, to support the development of products even without a clear business plan. Government agencies have also announced liberal schemes to fund/support innovation, fast-tracking applications for funding new projects, commercialization of prototypes, scaling-up production of existing products, etc. The emphasis on rapid development of products rather than restricting to proof-of-concept or prototypes bodes well for India as a whole (well beyond the COVID-19 situation). All these are laudable effects.

Government Ministries, State Governments and national organizations (notably. the Department of Science \& Technology, Department of Biotechnology, Defense Research and Development Organization, Council for Scientific and Industrial Research, etc.) have liberally promoted innovation in recent weeks through competitive calls for proposals to manage the COVID-19 pandemic effectively. Similar efforts have been made by the private sector, including associations such as the Federation of Indian Chambers of Commerce and Industry, private companies, and crowdsourced platforms. 
On the other hand, the race for innovation has triggered a wave of unregulated competition, duplication, plagiarism, and often complete disregard for the principles of protecting intellectual property (IP). Many innovators created hype rather than hope with their innovations. Even prestigious Government agencies/institutions are compiling reports and brochures, rather than ensuring that useful products reach the intended end user. Thus, there is more innovation on paper than in reality. Further, the urgency for solutions compressed the timelines for innovation; hence, half-baked solutions are being released without appropriate testing. Worse, none of the products intended for

Table 1 Partial list of innovative products and processes in India related to healthcare delivery for COVID-19

\begin{tabular}{|c|}
\hline Respiratory support devices \\
\hline Mechanization of manual ventilation \\
\hline Artificial Breathing Capability Device \\
\hline Ventilator splitter adapters \\
\hline Oxygen delivery splitter devices \\
\hline Personal protective equipment products \\
\hline Face masks \\
\hline Face shields and splash guards \\
\hline Intubation boxes \\
\hline Aerosol guard boxes \\
\hline Sanitation products and solutions \\
\hline Indigenous hand sanitizers \\
\hline Ultraviolet light emitters \\
\hline Ozone \\
\hline Silver-based products \\
\hline Others \\
\hline Diagnostics \\
\hline Indigenous antibody-based testing kits \\
\hline Polymerase chain reaction-based diagnostic kits \\
\hline Loop-mediated isothermal amplification \\
\hline $\begin{array}{l}\text { Repurposing and/or retrofitting existing products and } \\
\text { solutions }\end{array}$ \\
\hline Telehealth solutions (conventional and adapted versions) \\
\hline Tele-education solutions (for professionals, students, public, etc.) \\
\hline Telemeeting solutions (i.e., platforms for communication) \\
\hline Remote patient monitoring systems repurposed for COVID-19 \\
\hline Wearable devices adapted for COVID-19 \\
\hline GPS-enabled technologies adapted as COVID trackers \\
\hline $\begin{array}{l}\text { Artificial intelligence-enabled platforms for automation of } \\
\text { radiological diagnosis, patient monitoring, environmental } \\
\text { monitoring, etc }\end{array}$ \\
\hline Railway coaches used as isolation wards \\
\hline $\begin{array}{l}\text { Hotels, hostels, factory floorspace, etc. converted to quarantine } \\
\text { facilities }\end{array}$ \\
\hline Robots used for contactless delivery of medications, etc \\
\hline $\begin{array}{l}\text { Drones used for sanitization, transportation of small objects, and } \\
\text { public health messaging }\end{array}$ \\
\hline COVID-19 bus \\
\hline IT solutions adapted for COVID-19 management \\
\hline
\end{tabular}

clinical use have undergone clinical validation. Therefore, many of the products being developed are unlikely to be usable in the clinical or public health domains. Most innovators fully realize that their designs are not novel hence there is no scope of filing patent applications. Such innovators immediately publicize their unoriginal innovations/imitations to the lay press "in the national interest." In contrast, serious innovators are unable to share their innovations until IP is protected. This has created an ironic situation, wherein genuine innovations are unknown to the public, whereas unoriginal ideas and prototypes are widely available for public discussion.

\section{Common Features of COVID-19 Related Innovations and Imitations in India}

The wealth of ideas has resulted in a plethora of low-tech innovation and imitation products. However, very few high-quality products have been developed. Most of the "innovative products" represent technology solutions without end user considerations.

Therefore, none of the products have been clinically validated for efficacy and safety of the end user (i.e., healthcare worker or patient). This is equally true for potentially life-saving innovations (such as respiratory support devices) and products for prophylaxis (such as sanitizers, PPE components, etc.). Thus, most of the innovations and imitations have little potential to change the healthcare scenario related to COVID-19 or otherwise.

\section{What is the Way Forward?}

Biomedical innovation is a process, not merely an outcome. -Fig. 1 shows a schematic diagram of this concept. The process should begin from a thorough understanding of the healthcare need(s) of the end user, namely, healthcare provider, patient, or public health system. This stimulates novel ideas to address the lacunae in the existing solutions, leading to the development of a novel prototype or product. This needs extensive laboratory testing, followed by clinical validation before it can be processed for regulatory approval and ultimately reach the

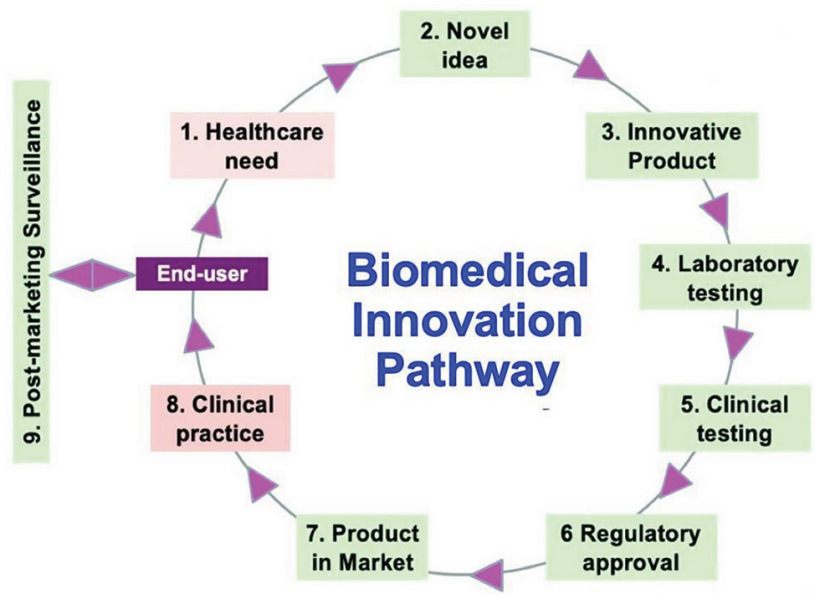

Fig. 1 Schematic showing the innovation pathway for biomedical products. 


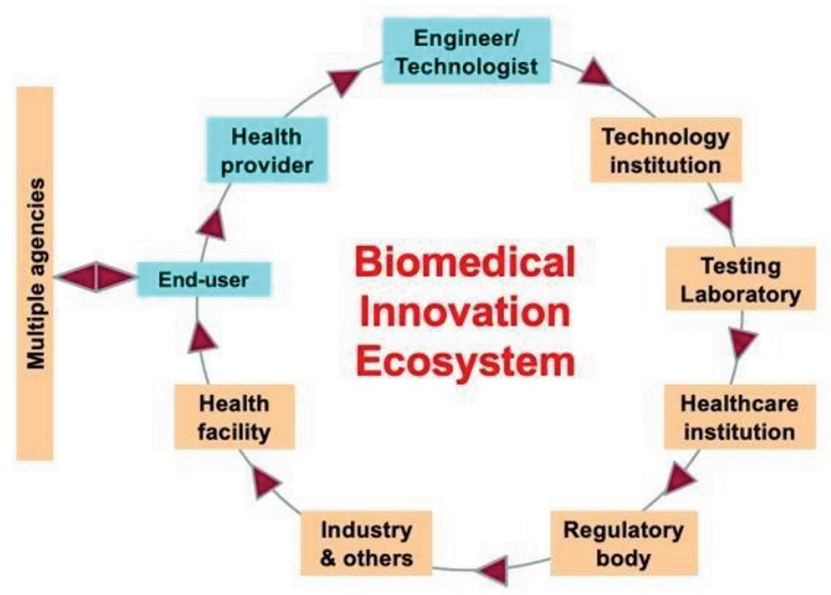

Fig. 2 Schematic showing a biomedical innovation ecosystem.

market. Once deployed in the clinical setting, postmarketing surveillance is essential to ensure efficacy and safety for the end users. Most innovators try to short-circuit the process from step 3 directly to step 7 or 8 . Many innovators believe that once a prototype or product is ready, someone else should take up the responsibility for the subsequent steps to make the product usable in the real world.

Successful innovation also requires an ecosystem wherein individuals, institutions, organizations, and Government agencies work together to facilitate the flow of an innovative idea to its final destination, that is, the end user. - Fig. 2 shows a schematic representation of this concept. The ecosystem requires close coordination and cooperation amongst multiple stakeholders, without unhealthy competition. The current COVID-19 inspired innovation race lacks this system; therefore, considerable resources are being wasted rather than being concentrated toward useable innovative products.

\section{Fruits of COVID-19 Inspired Innovation in India}

The following section briefly highlights some innovations that are either inspired by the COVID-19 pandemic or can have application in this situation.

\section{Respiratory Support Devices}

The shortage of mechanical ventilators in developed and developing countries (to meet the need posed by COVID-19) spawned an international as well as domestic race to develop solutions.

\section{Mechanization of Manual Ventilation}

Manual ventilation by compressing self-inflating bags (SIBs) is common in most busy Indian hospitals, even before the COVID-19 pandemic. Although it is an uncontrolled process, it is life-saving in situations where mechanical ventilators are inaccessible, unavailable, or unaffordable. The inherent problems with manual ventilation are that ventilation rate, volume, and pressure are uncontrolled resulting in hypoor hyperventilation. There is often dys-synchrony with the patient's spontaneous respiratory efforts or cough, no control over situations like endotracheal tube block, displacement, disconnection, etc. Finally, manual ventilation entails tremendous physical, emotional and mental fatigue in persons performing ventilation.

The COVID-19 pandemic stimulated the re-exploration of efforts to automate compression of SIBs, which itself is not a new concept. ${ }^{8,9}$ In recent weeks, several innovators in various countries ${ }^{10-14}$ including India ${ }^{15-25}$ devised mechanical solutions for manual ventilation. Most of these mechanize the compression of the SIB at a preset rate using motors controlled by microprocessors. Some of these devices can be operated using smartphone apps..$^{15,16}$ One institution went a step further and reported capability to compress two bags with one machine. ${ }^{26}$

Although these devices appear to be attractive solutions, they fail to overcome the inherent problems associated with manual ventilation, as there is no control over ventilation pressure, volume and ratio of inspiratory to expiratory time. This creates the same risks of barotrauma and dys-synchrony noted with manual ventilation. These devices could even be harmful if the SIB gets compressed when the patient is breathing out, thereby driving air rich in carbon dioxide back into the lungs. Further, most of the innovators have not considered how the device can be connected to a patient.

However, all these devices share the common features of extremely rapid development, low(er) price, expansive claims of the device capabilities for COVID-19 patients, lack of clarity of which ventilation parameters can be controlled, extensive publicity in the lay press (without technical details), paucity of laboratory testing data for suitability in clinical care, and absence of clinical validation. Ultimately, most of these devices are unsuitable for clinical use.

\section{Artificial Breathing Capability Device}

A group of innovators led by the first author successfully invented and tested a novel 'Artificial Breathing Capability Device' (ABCD). This device was conceptualized in 2015, well before the COVID-19 pandemic, as a safer and more efficacious alternative to manual ventilation. Design and development phases were completed during $2016-18,{ }^{27}$ and patent application filed in May 2018..$^{28}$ - Fig. 3 shows the device.

ABCD comprises an electromechanical system compressing a SIB, with the unique feature of controlling ventilation by permitting users to set peak inspiratory pressure (PIP), respiratory rate (RR), and inspiration:expiration time ratio (I:E ratio). The present version of the device can deliver PIP in the range of 10 to $50 \mathrm{~cm} \mathrm{H2O}$, RR in the range 10 to 60 per minute, and I:E ratio in the range 1:1 to $1: 4$ (with any fraction in between). This covers most clinical situations requiring respiratory support. Another unique feature of the device is that an exhalation valve is placed just distal to the endotracheal tube; hence, there is no risk of rebreathing expired air. Further, a pressure sensor placed at the same location enables the recording and real-time display of the actually delivered pressure, rate and inspiratory time, with each breath. The device has multiple smart features including self-regulatory checks, cough alarm with temporary cessation of ventilation, 

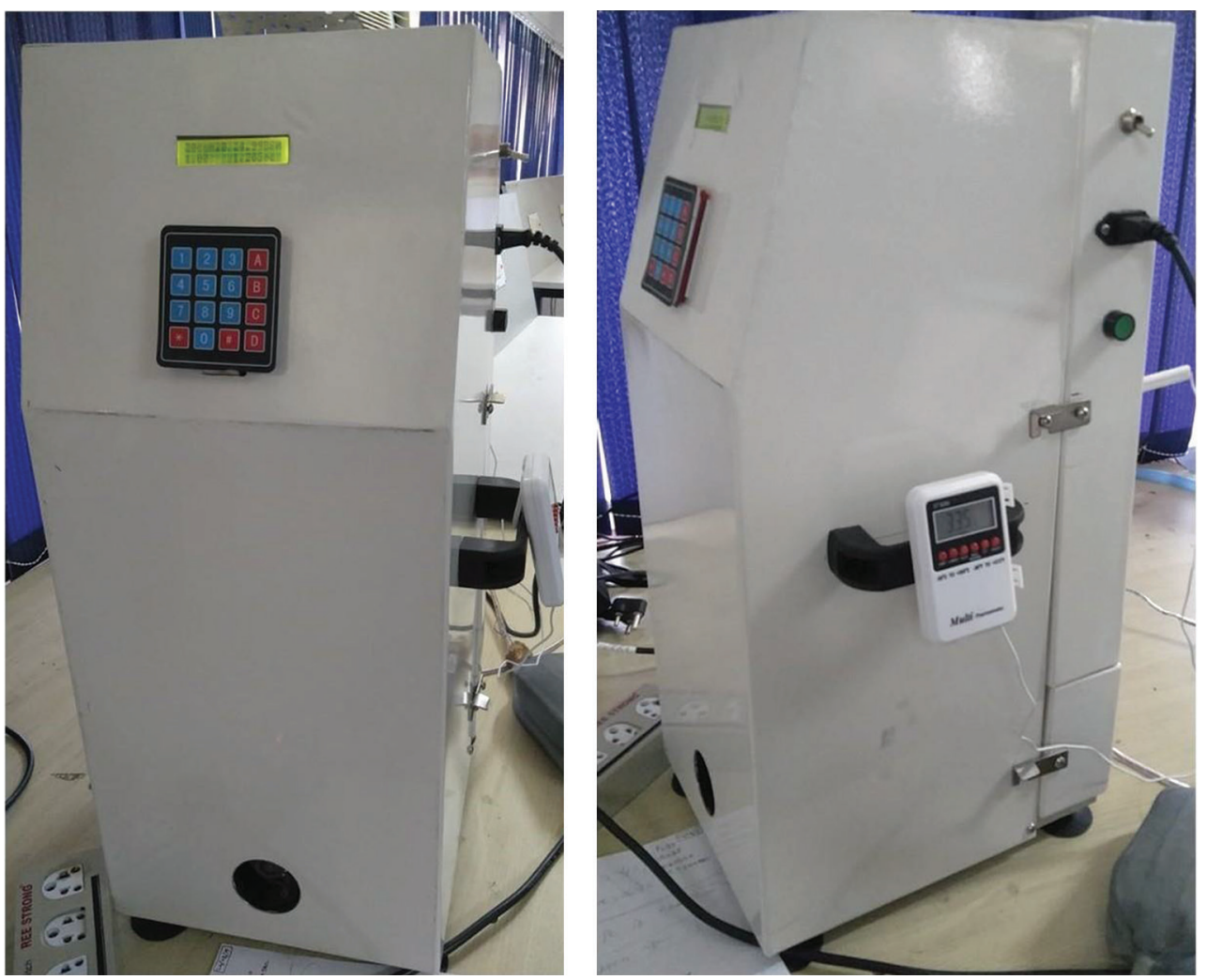

Fig. 3 Front view and side view of the Artificial Breathing Capability Device (ABCD).

endotracheal tube disconnection alarm, endotracheal tube blockage alarm, and bag disconnection alarm.

ABCD was extensively tested using 396 combinations of user settings, and nonstop functioning for 60 continuous days in the laboratory. ${ }^{29}$ It was also tested on a patient simulator in PGIMER Chandigarh, proving its capabilities. Clinical testing on live patients has been initiated with due approval of the Institutional Ethics Committee ( - Fig. 4).

Although the ABCD is safer and more efficacious than manual ventilation, and well ahead of the current wave of devices compressing ambu bags, it requires further refinements to make it suitable for the ventilatory needs of COVID-19 patients. This process is currently underway and $A B C D 2.0$ is expected to be available for clinical testing in 2 to 3 months.

\section{Ventilator Splitter}

This is a simple mechanical device, permitting one ventilator to ventilate more than one patient simultaneously. This is achieved by using a plastic connector (often $3 \mathrm{D}$ printed) to "split" the ventilator output to reach multiple patients. The exhaled air is similarly returned from multiple patients. Naturally, the system can work only if all patients require exactly the same ventilatory settings. Such splitters are not entirely novel and were used previously in the 2017 Las Vegas mass shooting, where most of victims were young

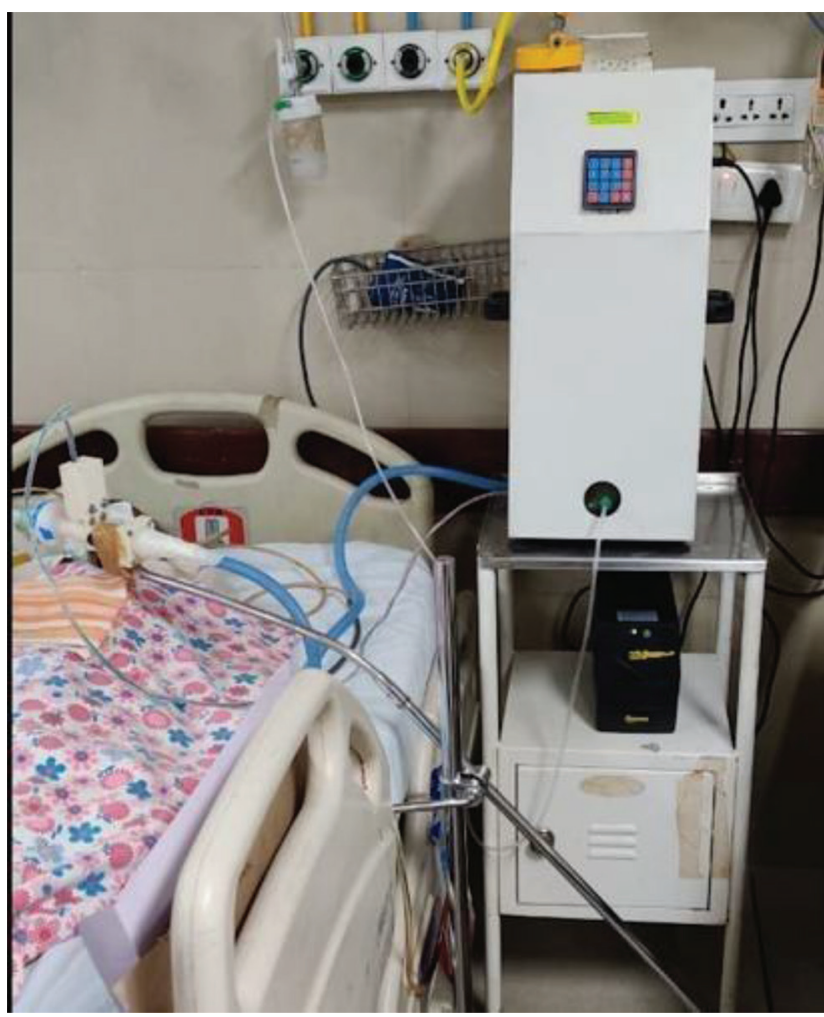

Fig. 4 Patient being ventilated using $A B C D$ in the emergency ward. $A B C D$, artificial breathing capability device. 
healthy adults (with normal lungs requiring physiological ventilation parameters). ${ }^{30}$ However, their utility in the context of COVID-19 is uncertain, since ventilatory support of various patients may not be similar, and the risk of cross-contamination is significant. Nevertheless, several Indian innovators imitated the design ${ }^{31-36}$ with wide media publicity, although none has been clinically validated.

\section{Oxygen Delivery Splitter}

In many Indian hospitals, general wards lack sufficient oxygen points/ports to ensure individualized delivery of oxygen to patients. Many such wards have recently been converted to COVID-19 wards, necessitating assured oxygen supply at every bed. For years, the deficiency of oxygen ports was solved by using Y connectors to split the oxygen flow to reach multiple patients. Naturally, such methods require high-flow of oxygen from the source. This innovation may ensure oxygen at every bed in COVID-19 wards, although it is not known whether they can fulfil the high-oxygen demand of some COVID-19 patients.

\section{Innovations in Personal Protective Equipment Products Face Masks}

An institution in Bengaluru developed a face mask comprising a sheet of nylon or silk sandwiched between polypropylene layers. ${ }^{37}$ Rubbing the layers against each other creates a negative charge on the outer layer, whereas nylon gets a positive charge. The double electric charge reportedly protects users from inhaling the Coronavirus. The practical utility of masks requiring rubbing is questionable, given that masks used in COVID-19 are not to be touched by hand at all.

A student of class XI from West Bengal successfully developed an "air providing and virus destroying mask" within 7 days. $^{38}$ Lay press coverage reported that "dust particles and harmful elements" somehow get "trapped in water particles and the lipid proteins of the virus are destroyed." A one-way valve then ensures that "clean air can enter the patient's lungs." During expiration, "air exits through another one-way valve and enters another reservoir-container in which the lipid protein of the virus is broken down to destroy it." Despite these vague details, the Ministry of Science and Technology plans to take this innovation forward.

A private company developed a reusable N95 mask, with viral filtration efficiency of $99.7 \%$, claiming it as the world's first mask having a "nanotech filter ${ }^{39}$." Apparently, the mask serves to trap the "virus particles, dry them out and break them apart."

A pharmacy training institution in Vadodara developed a triple-layer mask impregnated with "enzymes and chemical reagents that can copy DNA to RNA." The institution claimed that contact of the mask with "Coronavirus particles" triggers a reaction, causing the mask to change color. ${ }^{40}$

The Times of India newsgroup launched the "Mask India movement" to encourage people to design and use masks. ${ }^{41}$ Apparently more than 1 lakh entries were received, and the movement was commended by the Prime Minister of India. However, the website shows only fabric masks in different designs, shapes and colors. ${ }^{42}$

\section{Face Shields and Splash Guards}

Various innovators designed and developed face shields or splash guards. Most either repurposed existing helmet visors or simply attached (overhead projector) transparency to plastic or rubber headbands. The attachments range from crude stapling to buttons or studs. Variations include 3D printing of the plastic parts. The Ministry of Health and Family Welfare's recent specifications for face shields recommended that they be composed of clear plastic, ensure good visibility, have an adjustable headband, snug fit, be preferably fog resistant, and could be reusable. ${ }^{43}$ They should also be compliant with two international standards, that is, "EU standard directive 86/686/EEC, EN 166/2002" or “ANSI/ SEA Z87.1-2010." However, these standards include much more stringent specifications. A footnote states that the item should be accompanied with certification of analysis from national/international organizations/laboratories, indicating conformity to standards" and expiry date of 5 years. Clearly, none of the Indian innovations fulfil these criteria.

\section{Intubation Boxes and Aerosol Guards}

A variety of acrylic/plastic boxes have been manufactured to protect healthcare workers from aerosol generated during patient care. The general design includes a box with openings to insert the operator's hands. Depending on the intended usage, the box may be open at one end (if it is to be placed over the patent's head) or completely closed (if used for laboratory processing of samples). Although these boxes are based on an open-source design shared by a Taiwanese physician, ${ }^{44}$ many Indian individuals and institutions have claimed to have "developed" it with or without additional refinements. ${ }^{45-48}$ The first author has encountered 23 variants of the box design in his own institution, and contributed to designing one for laboratory technicians handling biological specimens of suspected COVID-19 patients. Despite being imitations, the numerous variations making them fit-for-purpose is a tribute to the Indian spirit of innovation. These boxes are one of the few innovations that can be successfully deployed in hospitals managing COVID-19 patients, although their safety needs verification.

\section{Innovations in PPE}

The overall design of PPE including hazmat suits is not very complex. The challenge with indigenous innovation is mass producing them rapidly, yet with efficacy and safety. The Indian Navy is producing a cheap(er) PPE "developed" by a naval physician, which has been tested and validated by an (undisclosed) Indian Council of Medical Research (ICMR)approved testing laboratory. ${ }^{49}$ It is composed of a "special fabric" with "high breathability."

IIT Ropar scientists have "created" a machine to clean and sterilize PPE using "ultrasonication, UV-C irradiation and oxidizing treatment." 50

A startup company claims to have developed antibacterial clothing for hospital personnel, using nanosilver. ${ }^{40}$ It is unclear how an antibacterial coating will work against the Coronavirus. 


\section{Sanitization Solutions}

\section{Indigenous Hand Sanitizer Solutions}

A south Indian University prepared conventional hand sanitizer on its campus and distributed it to the district health department authorities. ${ }^{51}$ Similarly, the Defense Research and Development Organization (DRDO) also produced a hand sanitizer in one of its laboratories. ${ }^{52}$ An alcohol-free cow urine-based sanitizer prepared from "distilled cow urine obtained from indigenous cows" mixed with "aromatic essential oil and Ganga jal" is also described on various Internet sites. ${ }^{53,54}$

\section{Ultraviolet Light Emitters}

Many innovators have developed gadgets using ultraviolet light to "kill the COVID-19 virus" since light with 200 to $300 \mathrm{~nm}$ (peak $254 \mathrm{~nm}$ ) wavelength can kill bacteria and viruses. These gadgets include units such as boxes/suitcases to disinfect small objects, $, 5,56$ cabinets and trolleys, ${ }^{57}$ full-person sanitation boxes, ${ }^{58}$ and larger towers to disinfect rooms ${ }^{40}$ or even public spaces. ${ }^{59}$ The "disinfection time" with these gadgets is variously described as 3 minutes to 30 minutes, but there is no way to test efficacy.

\section{Ozone}

A mineral water manufacturing company has developed disinfection chambers, wherein medical-grade ozone is produced and sprayed in a chamber ${ }^{60}$ to decontaminate clothes and exposed parts of the body. Placed in front of hospitals in Mumbai, it "sanitizes" personnel entering or leaving this hospital within 30 seconds.

\section{Silver}

A startup company developed alcohol-free aqueous-based colloidal silver solution to disinfect hands and surfaces. ${ }^{61}$ Other agencies reported similar developments. ${ }^{62}$ The principle is that the silver nanoparticles were previously documented to be effective against HIV, Hepatitis B virus, etc. It is expected that colloidal silver may block RNA replication of the Coronavirus and its infectivity by blocking the surface glycoproteins.

\section{AU Sanitizer}

Recently, the National Hub for Healthcare Instrumentation Development (NHHID) claimed the development of a unique sanitizer, incorporating a RNA degrading enzyme, that destroys all Coronavirus components, including its genetic material. ${ }^{63}$ It seems that this product can work as a standalone disinfectant but can also be mixed with existing alcohol-based solutions. The product is reported to be highly efficacious and very cheap.

\section{Disinfection Tunnels}

An innovator in Tamil Nadu popularized the concept of disinfection tunnels in India. Basically, it is a narrow passage embedded with hundreds of nozzles to spray disinfectant (usually $1 \%$ hypochlorite) onto people walking through the passage. ${ }^{64}$ This "development" triggered a race of copycat innovations using the same or different disinfectant chemicals. One site installed such a tunnel to spray an ayurvedic product called rajat bhasma. ${ }^{65}$ However, it soon became apparent that disinfection tunnels could be more harmful than beneficial. ${ }^{66}$ Official agencies rapidly discouraged and then banned the use of such tunnels. Various explanations were offered, ${ }^{67}$ rather than simply citing absence of efficacy and safety.

\section{Environmental Sanitization Solutions}

A Delhi-based company claimed to have developed a machine that discharges highly ionized water droplets which can oxidize the protein of Coronavirus. ${ }^{68}$ The technology ostensibly combines electric energy and water atomization to induce a charge on water droplets. This has apparently been designed to rapidly sanitize large public spaces such as hospitals, transportation hubs, marketplaces, etc.

Another private company developed an antimicrobial coating claimed to be efficacious against viruses for as long as 3 months. ${ }^{69}$ This chemical is being used to sanitize the fleet of vehicles of the Gurugram Police Department.

The Indian Army has deployed quadcopters (described as drones with four rotors) to spray up to $5 \mathrm{~L}$ of disinfectant chemicals from a height of $10 \mathrm{~m}$ to sanitize larger areas within a few minutes. ${ }^{70}$

\section{Diagnostic Testing \\ Rapid Antibody-Based Kits}

On May 14, 2020, ICMR listed 10 antibody-based rapid diagnosis test kits manufactured in India which were satisfactorily validated by the National Institute of Virology. ${ }^{71}$ The ICMR document included a disclaimer that the test kits were validated under laboratory conditions and there could be performance variability in field conditions. It also advised that the kits were not intended for diagnosis of COVID-19 infection.

\section{Real-Time PCR Diagnostic Kits}

The ICMR website hosted a document dated May 16, 2020, reporting that a total of 71 RT-PCR kits were evaluated and 37 were found to be satisfactory. ${ }^{72}$ However, news reports indicate that other diagnostic kits are also expected to be available in the immediate future. One of these products include a probe free RT-PCR based kit developed at IIT Delhi. ${ }^{73}$

\section{Loop-Mediated Isothermal Amplification}

Sree Chitra Tirunal Institute for Medical Sciences and Technology (SCTIMST) has developed a diagnostic kit based on reverse tranase loop-mediated amplification of viral nucleic acid technology. ${ }^{74}$ The method has high-specificity as it detects two regions of the Coronavirus gene. SCTIMST scientists claim that the test detection time is only 10 minutes, and total time from receiving the sample to delivering the report is under 2 hours. The technology will make testing far cheaper than existing methods. However, ICMR approval is pending. Another private company also developed a diagnostic platform using LAMP technology. ${ }^{75}$ 


\section{Conclusion}

The current COVID-19 pandemic has created an unprecedented demand for the rapid development of technological solutions for widespread healthcare needs. This has triggered innovation among individuals, institutions, and organizations. Although there are several laudable characteristics of the innovation effort, it has raised new challenges and problems as well. The way forward is to encourage innovation through a rational pathway, starting from the needs of the end users and guiding the process through the various logical steps back to the end user. This requires a complex interplay amongst various stakeholders through an innovation ecosystem, so that the country can benefit from the process during the COVID-19 pandemic and beyond.

\section{Authors' Contributions}

J.L.M. conceptualized the manuscript, undertook literature survey, and prepared and finalized the manuscript. T.L.M. provided critical appraisal and intellectual inputs.

\section{Funding}

None.

\section{Conflict of Interest}

None declared.

\section{References}

1 Luo H, Galasso A. The One Good Thing Caused by COVID-19: Innovation. Available at: https://hbswk.hbs.edu/item/theone-good-thing-caused-by-covid-19-innovation. Accessed May 15, 2020

2 India: How Coronavirus Sparked a Wave of Innovation. Available at: https://theconversation.com/india-how-coronavirus-sparked-a-wave-of-innovation-135715. Accessed May 16,2020

3 Merriam-Webster Dictionary. Available at: https://www.merriam-webster.com/dictionary/innovation. Accessed May 12, 2020

4 Cambridge Dictionary. Available at: https://dictionary.cambridge.org/dictionary/english/innovation. Accessed May 13, 2020

5 Wikipedia. Available at: https://en.wikipedia.org/wiki/ Innovation. Accessed May 13, 2020

6 Business Dictionary. Available at: http://www.businessdictionary.com/definition/innovation.html. Accessed May 13, 2020

7 Wikipedia. Available at: https://en.wikipedia.org/wiki/Jugaad. Accessed May 13, 2020

8 Bergman RT. Ambu-bag automation system and method. International Application Published Under The Patent Cooperation Treaty (PCT). International Publication Number WO 2011/022112 A3. Available at: https://patentimages.storage.googleapis.com/0d/5b/3c/2e57418ee200d3/ WO2011022112A3.pdf. Accessed March 30, 2020

9 Bergman RT. Ambu bag automation system and method. United States Patent Application Publication. Publication Number US 2011/0041852 A1. Available at: https://patentimages.storage.googleapis.com/d8/ce/df/f378c200595e3f/ US20110041852A1.pdf. Accessed March 26, 2020

10 Zhou C. University of Minnesota Develops Simpler, Inexpensive Mechanical Ventilator. Available at: https://www.medgadget. com/2020/03/university-of-minnesota-develops-simpler-inexpensive-mechanical- ventilator.html. Accessed March 30, 2020
11 Beech P. These New Gadgets Were Designed to Fight COVID19. Available at: https://www.weforum.org/agenda/2020/04/ coronavirus-covid19-pandemic-gadgets-innovation-technology/. Accessed May 14, 2020

12 Cook K. Volunteer Team Develops Affordable Ventilator. Available at: https://www.kgw.com/article/news/health/volunteer-team-develops-affordable-ventilator/283-0d02d08a-d1a4480f-bae4-725fc50e4311. Accessed May 18, 2020

13 Welsh Doctor Uses Military Experience to Design Ventilator That Will Help Coronavirus Patients. Available at: https:// www.walesonline.co.uk/news/health/welsh-doctor-uses-military-experience-17970315. Accessed May 16, 2020

14 COVID-19 Ventilators: The Two Best Innovations, An Indian US $\$ 1,700$ Toaster-Sized Ventilator and A US\$75 Open Source Ventilator from Spain. Available at: https://www.thailandmedical.news/news/covid-19-ventilators-the-two-best-innovations,-an-indian-us $\$ 1,700$ - toaster-sized-ventilator-and-aus\$75-open-source-ventilator-from-spain. Accessed May 16, 2020

15 Indian Institute of Technology Kanpur: Standard Chartered Bank FirstEntitytoFundVentilatorPrototypebyIITKanpur.Availableat: https://www.business-standard.com/article/news- ani/indianinstitute-of-technology-kanpur-standard-charteredbank-first-entity-to-fund-ventilator-prototype-by-iitkanpur-120040700345_1.html. Accessed May 16, 2020

16 BW Online Bureau. IIT Hyderabad CfHE-Incubated Startup Develops Low-Cost \& Portable Emergency Use Ventilator. Available at: http://bweducation.businessworld.in/article/IITHyderabad-CfHE-Incubated-Startup-Develops-Low-CostPortable-Emergency-Use-Ventilator-/03-04-2020-188175/. Accessed May 16, 2020

17 Bora G. Rising Covid-19 Cases Scare Hospitals with Insufficient Ventilators. Available at: https://economictimes.indiatimes. com/small-biz/sme-sector/covid-19-ventilators-hospitalsagva-healthcare-coronavirus/articleshow/74840459. cms?utm_source $=$ contentofinterest\&utm_medium $=$ text\&utm_campaign=c ppst. Accessed May 15, 2020

18 Watch: How the World's Lowest-Cost 'Made in India' Ventilator. Available at: https://timesofindia.indiatimes.com/ gadgets-news/watch-how-the-worlds-lowest-cost-madein-india-ventilator-works-without-electricity/articleshow/ 75243170.cms. Accessed May 17, 2020

19 Indian Railways Develops Low-Cost Ventilator 'Jeevan', Seeks ICMR Approval. Available at: https://economictimes. indiatimes.com/industry/transportation/railways/railwaysdevelops-low-cost-ventilator-jeevan-seeks-icmr-approval/ articleshow/74996857.cms?from=mdr. Accessed May 17, 2020

20 Nanda PK. IIT-Roorkee, AIIMS-Rishikesh Develop Low-Cost Portable Ventilator. Available at: https://www.livemint.com/ news/india/covid-19-iit-roorkee-develops-low-cost-portableventilator-offers-to-industry-11585842779864.html.Accessed May 17, 2020

21 Hyundai Motor India Develops Automatic Ambu Bag Actuator Prototype. Available at: https://auto.hindustantimes.com/auto/ news/hyundai-motor-india-develops-automatic-ambu-bag-actuator- prototype-41587208914044.html. Accessed May 17, 2020

22 Rana C. Chandigarh: PGIMER Doctor Creates Automatic AMBU Ventilator. Available at: https://indianexpress.com/article/cities/chandigarh/chandigarh-pgimer-doctor-creates-automatic-ambu-ventilator-6332803/. Accessed March 31, 2020

23 Karnataka Based Startup Comes Up with Automatic Ambu Bag. Available at: https://www.newindianexpress.com/states/ karnataka/2020/apr/05/karnataka-based-startup-comes-upwith- automatic-ambu-bag-2126133.html. Accessed May 17, 2020

24 SCTIMST Ties Up with Wipro 3D To Make Automated Ventilators. Available at: https://economictimes.indiatimes. com/industry/healthcare/biotech/healthcare/ctimst-ties-up- 
with-wipro-3d-to-make-automated-ventilators/articleshow/74960457.cms. Accessed May 17, 2020

25 COVID-19: NIT-Durgapur Builds Artificial Breathing Device. Available at: https://www.businessinsider.in/india/news/ covid-19-nit-durgapur-builds-artificial-breathing-device/articleshow/75126729.cms. Accessed May 17, 2020

26 Khanna B. Ventilator That Can Treat Two Patients, Courtesy IIT Ropar Scientists. Available at: https://timesofindia.indiatimes. com/home/education/news/ventilator-that-can-treat-twopatients-courtesy-iit- ropar-scientists/articleshow/74967790. cms. Accessed May 17, 2020

27 Mathew JL, Sharma M, Kumar N. Sukesha. Artificial Breathing Capability Device (ABCD): A Novel Life- Saving Device for Resource-Limited Settings. Presentation at 4th Global Forum on Medical Devices, Visakhapatnam, 12-14 December 2018. Available at: https://www.who.int/medical_devices/global_ forum/73_Artificial_Breathing_Capability_Device_novel_ life_s aving_device_limited_resources.pdf. Accessed May 17, 2020

28 WIPO IP Portal. WO2019229776 - Automated Artificial Breathing Device. Available at: https://patentscope.wipo.int/ search/en/detail.jsf?docId=WO2019229776\&_cid=P11-KACLNC-27872-1. Accessed January 12, 2020

29 Mathew JL, Sharma M, Sukesha GA, Kumar N, Chander A, Mathew PJ. Artificial Breathing Capability Device: design, development, and testing. BMJ Innovations (Accepted for publication)

30 Graham C. Johns Hopkins Engineers Develop 3d-Printed Ventilator Splitters. Available at: https://hub.jhu.edu/2020/ 04/02/3d-printed-ventilator-splitters-for-covid-19/. Accessed May 17, 2020

31 Tamil Nadu: Ventilator Splitters Being 3D Printed in Case of Shortage for Covid-19 Patients. Available at: https:// www.indiatoday.in/india/story/tamil-nadu-ventilator-splitters-being-3d-printed-in- case-of-shortage-for-covid-19-patients-1668167-2020-04-17. Accessed May 17, 2020

32 Coronavirus: Childcare Startup Cradlewise Develops Splitter to Increase Ventilator Efficiency. Available at: https://yourstory.com/2020/04/coronavirus-childcare-startup-cradlewise-covid-19- ventilators. Accessed May 17, 2020

33 Badve A. Coronavirus India: Nagpur's Dr Anand Sancheti Develops Ventilator Splitters. Avilable at: https://www.sakaltimes.com/coronavirus-maharashtra/coronavirus-india-nagpur's-dr-anand-sancheti- develops-ventilator-splitters. Accessed May 17, 2020

34 Khandge S. Engg Students Develop Ventilator Splitter to Support Multiple Patients at One Time. Available at: https:// punemirror.indiatimes.com/pune/civic/engg-students-develop-ventilator-splitter-to-support-multiple- patients-at-onetime/articleshow/74973864.cms. Accessed May 17, 2020

35 3D Printing Technology to Design Splitters that Can Bridge Ventilators Shortfall in India. Available at: https:// www.prnewswire.com/in/news-releases/chandigarhuniversity-uses-3d-printing- technology-to-design-splittersthat-can-bridge-ventilators-shortfall-in-inia-888142073. html. Accessed May 17, 2020

36 Local Doctors Create Ventilator Splitters; They Can Only Be Used in Crisis Situations Say Experts. Available at: https:// www.nationalheraldindia.com/national/local-doctors-create-ventilator- splitters-they-can-only-be-used-in-crisis-situations-say-experts. Accessed May 17, 2020

37 Kumar C. Bengaluru Lab Develops Easy-To-Make Reusable 'Power' Mask. Available at: https://timesofindia.indiatimes. com/india/bengaluru-lab-develops-easy-to-make-reusable-power- mask/articleshow/75220726.cms. Accessed May 17,2020

38 Das J. Bengal Girl's 'Game-Changer Mask' for Covid-19 Patients Makes Central Agency's Shortlist. Available at: https://indianexpress.com/article/cities/kolkata/budwan-girlcovid-19-air-provider-and-virus-destroyer- mask-centralagency-nod-6381390/. Accessed May 17, 2020

39 Paljor A. Nirvana Being's N95 reusable Airific Masks are Right Fit and Filter. Available at: https://www.newindianexpress. com/cities/delhi/2020/apr/28/nirvana-beings-n95-reusableairific-masks-are-right-fit-and-filter-2136281.html. Accessed May 17, 2020

40 Intepat Team. A Gist of Indian Innovation to Combat COVID19. Available at: https://www.intepat.com/blog/indian-innovation-to-combat-covid-19/. Accessed May 17, 2020

41 The Times of India: Mask India Movement. Available at: https://campaignsoftheworld.com/digital/the-times-of-indiamask-india-movement/. Accessed May 17, 2020

42 MaskIndia Entries. Available at: https://timesofindia.indiatimes.com/maskindia/photos. Accessed May 17, 2020

43 Ministry of Health and Family Welfare Directorate General of Health Services [Emergency Medical Relief]. Novel Coronavirus Disease 2019(COVID-19): Guidelines on rational use of Personal ProtectiveEquipment.Availableat:https://www.mohfw.gov.in/ pdf/GuidelinesonrationaluseofPersonalProtectiveEquipment. pdf. Accessed May 12, 2020

44 Inventiva. Startup Group Works to Get Flat-Packed Protective Boxes to Front-Line COVID-19 Medical Workers. Available at: https://www.inventiva.co.in/trends/inventiva/startup-groupworks-to-get-flat-packed-protective-boxes-to-front-linecovid-19-medical-workers/. Accessed May 18, 2020

45 Singh B. IIT Guwahati Students Design Low-Cost Intubation Box to Help Doctors in Covid-19 Fight. Available at: https:// economictimes.indiatimes.com/industry/healthcare/biotech/healthcare/iit-guwahati-students-design-low-costintubation-box-to-help-doctors-in-covid-19-fight/articleshow/75475246.cms?from=mdr. Accessed May 18, 2020

46 Railways New Innovative Device, 'Intubation Boxes', to Aid the Medical Fraternity In Our Fight Against COVID-19. Available at: https://news.fresherslive.com/articles/railway-s-new-innovative- device-intubation-boxes-to-aid-the-medical-fraternity-in-our-fight-against-covid-19-126438. Accessed May 18, 2020

47 Dalvi A. Mahindra Starts Making Coronavirus-Combating Aerosol Box at Nashik Plant. Available at: https://www.autocarpro.in/news-national/mahindra-starts-making-coronaviruscombating-aerosol-box-at- nashik-plant-56196. Accessed May 18,2020

48 COVID-19: IIT Madras Start-Ups Develop PPEs Made From 3D Printers and Common Stationery Materials. Available at: https:/ www.edexlive.com/campus/2020/apr/30/covid-19-iit-madrasstart-ups-develop-ppes-made-from-3d-printers-and-commonstationery-materials-11697.html. Accessed May 18, 2020

49 Patenting of Innovative Low Cost PPE Developed by Indian Navy Paves Way for Rapid Mass Production. Available at: http:// ddnews.gov.in/national/patenting-innovative-low-cost-ppedeveloped-indian-navy-paves-way-rapid-mass-production. Accessed May 17, 2020

50 Khanna B. Innovation in Times of COVID-19. Available at: https:// timesofindia.indiatimes.com/india/innovations-in-times-ofcovid19/articleshow/74942548.cms. Accessed May 17, 2020

51100 Litres of Hand Sanitizer was Prepared at Karunya Deemed University. Available at: https://www.karunya. edu/news/100-litres-hand-sanitizer-was-prepared-karunya-deemed-university. Accessed May 17, 2020

52 Covid-19 in India: DRDO Manufactures Hand Sanitizer in Own Unit. Available at: https://timesofindia.indiatimes.com/videos/news/covid-19-in-india-drdo-manufactures-hand-sanitizer-in-own- unit/videoshow/74810774.cms. Accessed May 17,2020

53 Team Newsable. Will 'Cow Urine Hand Sanitizer' On Amazon Protect You from Coronavirus. Available at: https://newsable. 
asianetnews.com/india/will-cow-urine-hand-sanitizer-onamazon-protect-you-from- coronavirus-q6zaq2. Accessed May 17, 2020

54 Singh R. Amid Coronavirus Scare, Amazon Is Selling A 'Cow Urine Hand Sanitizer' But It's Clearly Ineffective. Available at: https://www.india.com/viral/amid-coronavirus-scare-amazon-is-selling-a-cow- urine-hand-sanitizer-but-its-clearly-ineffective-3967339/. Accessed May 17, 2020

55 Wangchuk RN. Bengaluru Startup Designs Disinfection Chamber for Parcels, Groceries \& Masks. Available at: https://www.thebetterindia.com/223668/bengaluru-startup-log9-coronaoven-covid19-innovation- disinfection-chamber-india-nor41/. Accessed May 17, 2020

56 IIT Ropar's Sanitizing 'Trunk' Using UV Light to Kill Covid-19 to Be Available at Rs 500. Available at: https://www.indiatoday. in/education-today/news/story/iit-ropar-creates-sanitizingtrunk-that-kills-covid-19-using-uv-light-1665432- 2020-0410. Accessed May 17, 2020

57 Department of Science and Technology. UV Disinfection Trolley Can Effectively Clean Up Hospital Spaces to Combat COVID-19. Available at: https://dst.gov.in/uv-disinfection-trolley-can-effectively-clean-hospital- spaces-combat-covid-19. Accessed May 17, 2020

58 UV Light Booth, Nasal Gel \& Other Innovations India's Working on To Battle Covid-19. Available at: https://theprint.in/science/ uv-light-booth-nasal-gel-other-innovations-indias-working-on-to- battle-covid-19/397999/. Accessed May 17, 2020

59 DRDO develops UV disinfection tower for malls, airports and other crowded places. Available at: https://timesofindia. indiatimes.com/gadgets-news/drdo-develops-uv-disinfection-tower-for-malls-airports-and-other-crowded-places/ articleshow/75540927.cms. Accessed May 17, 2020

60 BW Online Bureau. Bisleri Installs Ozone Disinfection Chambers Outside Mumbai Hospitals to Stop the Spread of COVID-19. Available at: http://bwhotelier.businessworld.in/article/BisleriInstalls-Ozone-Disinfection-Chambers-Outside-MumbaiHospitals-to-Stop-the-Spread-of-COVID-19/23-04-2020190122/. Accessed May 17, 2020

61 DST Funded Start-Up Develops Chemical Free Silver Based Disinfectant to Fight COVID 19 Pandemic. Available at: https:// dst.gov.in/dst-funded-startup-develops-chemical-free-silver-based- disinfectant-fight-covid-19-pandemic. Accessed May 17, 2020

62 BioVoice News desk. BARC Develops Nanosilver Coating That Can Kill Bacteria. Available at: https://www.biovoicenews. com/barc-develops-nanosilver-coating-that-can-kill-bacteria/. Accessed May 17, 2020

63 The Covai Mail. Anna University develops Novel Sanitizer to destroy Novel Coronavirus. Available at: https://www.covaimail.com/?p=26855. Accessed 30 May 2020

64 Saigal K. India's Disinfectant Tunnels - Emerging strategies to Combat Coronavirus. Available at: https://www.investindia. gov.in/team-india-blogs/indias-disinfectant-tunnels-emerging-strategies-combat- coronavirus. Accessed May 17, 2020

65 Chitravanshi R. Covid-19: Demand for Disinfectant Tunnels Grows as Malls, Offices, Line Up. Available at: https://www. business-standard.com/article/current-affairs/covid-19demand-for-disinfectant-tunnels-grows-as-malls-officesline-up-120042600562_1.html. Accessed May 17, 2020

66 Disinfectant Tunnel Could Have Harmful Effects, says PGIMER. Available at: https://www.thehindu.com/sci-tech/ health/disinfectant-tunnel-could-have-harmful-effects/article31348227.ece. Accessed May 17, 2020

67 Kulkarni S. Coronavirus: Centre Strongly Advises Against Spraying of Disinfectants on People. Available at: https://www. deccanherald.com/national/coronavirus-centre-stronglyadvises-against-spraying-of-disinfectants-on-people-827399. html. Accessed May 17, 2020

68 Varshney R. IIT and Stanford Alumni Develop Machine to Sterilise Public Places to Prevent The Spread Of Coronavirus. Available at: https://yourstory.com/2020/03/iit-stanford-alumni-machine-coronavirus-spread. Accessed May 15, 2020

69 Chakraborty N. Coronavirus: How Droom is Helping Gurgaon Police Beat COVID-19. Available at: https://yourstory. com/2020/04/coronavirus-startup-droom-gurugram-police. Accessed May 16, 2020

70 Indian Army has Disinfectant Drone, UV Gun That Kills Virus in Seconds in Its Covid Arsenal. Available at: https://theprint. in/health/indian-army-has-disinfectant-drone-uv-gunthat-kills-virus-in- seconds-in-its-covid-arsenal/402452/. Accessed May 17, 2020

71 Guidance on Rapid Antibody Kits for COVID-19. Available at: https://www.icmr.gov.in/pdf/covid/kits/Antibody_based_ tests_14052020.pdf. Accessed May 18, 2020

72 Performance Evaluation of Commercial Kits for Detection of SARS-CoV-2. Available at: https://www.icmr.gov.in/pdf/covid/ kits/Real_time_PCR_tests_16052020.pdf. Accessed May 18, 2020

73 Press Trust of India. Bengaluru Firm to Produce IIT Delhi's COVID-19 Testing Kit. Available at: https://www.ndtv.com/ india-news/coronavirus-bengaluru-firm-to-produce-iit-delhis-covid-19-testing-kit- 2227795. Accessed May 18, 2020

74 A Research Institute in Kerala Has Developed A New, Faster and Cheaper Diagnostic Test For COVID-19 Which Could Be A Major Breakthrough. Available at: http://ddnews.gov.in/health/indianscientists-develop-low-cost-diagnostic-test-kit-covid-19. Accessed May 18, 2020

75 Fernandes S. Innovations in Covid-19 diagnosis reach pilot test stage. Available at: https://www.hindustantimes.com/ mumbai-news/innovations-in-covid-19-diagnosis-reachpilot-test-stage/story-N1AbqWGfEGBocnWlwyiGNK.html. Accessed May 18, 2020 